Nat. Hazards Earth Syst. Sci., 18, 907-919, 2018

https://doi.org/10.5194/nhess-18-907-2018

(C) Author(s) 2018. This work is distributed under

the Creative Commons Attribution 4.0 License.

\title{
Māori oral histories and the impact of tsunamis in Aotearoa-New Zealand
}

\author{
Darren N. King ${ }^{1,2}$, Wendy S. Shaw ${ }^{2}$, Peter N. Meihana ${ }^{3}$, and James R. Goff $f^{3,2}$ \\ ${ }^{1}$ Māori Environmental Research Centre - Te Kūwaha o Taihoro Nukurangi, \\ National Institute of Water and Atmospheric Research Ltd (NIWA), New Zealand \\ ${ }^{2}$ PANGEA Research Centre, School of Biological, Earth and Environmental Sciences, \\ University of New South Wales (UNSW), Australia \\ ${ }^{3}$ School of Humanities, Massey University, New Zealand
}

Correspondence: Darren N. King (darren.king@ @iwa.co.nz)

Received: 12 November 2017 - Discussion started: 23 November 2017

Revised: 7 Feburary 2018 - Accepted: 18 February 2018 - Published: 21 March 2018

\begin{abstract}
Māori oral histories from the northern South Island of Aotearoa-New Zealand provide details of ancestral experience with tsunami(s) on, and surrounding, Rangitoto (D'Urville Island). Applying an inductive-based methodology informed by "collaborative storytelling", exchanges with key informants from the Māori kin groups of Ngāti Koata and Ngāti Kuia reveal that a "folk tale", published in 1907, could be compared to and combined with active oral histories to provide insights into past catastrophic saltwater inundations. Such histories reference multiple layers of experience and meaning, from memorials to ancestral figures and their accomplishments to claims about place, authority and knowledge. Members of Ngāti Koata and Ngāti Kuia, who permitted us to record some of their histories, share the view that there are multiple benefits to be gained by learning from differences in knowledge, practice and belief. This work adds to scientific as well as Maōri understandings about tsunami hazards (and histories). It also demonstrates that to engage with Māori oral histories (and the people who genealogically link to such stories) requires close attention to a politics of representation, in both past recordings and current ways of retelling, as well as sensitivities to the production of "new" and "plural" knowledges. This paper makes these narratives available to a new audience, including those families who no longer have access to them, and recites these in ways that might encourage plural knowledge development and coexistence.
\end{abstract}

Whakarāpopototanga. Ko ngā kōrero tuku ā-waha Māori o Te Tauihu o te Waka a Māui e whakaahua nei i ngā wheako o ngā tūpuna ki te/ngā tai āniwhaniwha ki runga i te motu o Rangitoto, ki tōna takiwā anō hoki. Mā te whai i tētahi pūnaha, ko tōna tūāpapa ko ngā tirohanga ki te hapori, $\bar{a}$, he mea tohutohu hoki e 'te tuku kōrero ā-kāhui', i mārama ai i ètahi whakawhitinga kōrero ki ètahi māngai matua o ngā iwi Māori o Ngāti Koata me Ngāti Kuia, tērā têtahi 'pūrākau' i tāngia i te tau 1907, ka taea tōna whakataurite me tōna whakakotahi atu ki ētahi kōrero tuku ā-waha e ora tonu nei, kia whai tirohanga ai ki ètahi aituā parawhenua waitai nui o nehe. Ko ēnei momo kōrero tuku he whai wheako maha, he whai tikanga maha anō hoki, mai i te whakamaumahara i ètahi tūpuna o nehe me ngā mahi i oti i a rātou, tae atu ki ngā kōrero mō te rohe, mō te mana, mō te mātauranga anō. Ko tā ngā mema o Ngāti Koata me Ngāti Kuia i tuku kia hopukina ètahi o ā rātou kōrero tuku e whakaae nei, he hua nui ka puta i te whai māramatanga ki ngā rerekētanga ā-mātauranga, à-tikanga, ā-whakapono anō. Ka whakawhānui tēnei mahi i ngā māramatanga ā-pūtaiao, otirā, i ngā māramatanga o te Māori ki ngā pūmate o te tai āniwhaniwha (me ngā kōrero tuku anō). He mea whakatauira anō e tēnei, e whai kiko ai te whai wāhi atu ki ngā kōrero tuku ā-waha Māori (me te iwi e hono ā-whakapapa ana ki ngā kōrero), me aro pū ki te taha tōrangapū o te tū hei māngai mō tangata kē, ki ngā hopukanga kōrero o mua, ki ngā ara tuku kōrero anō o nāianei, ā, me aro pū hoki ki ngā kaupapa mana nui me mātua whakaaro i te whakaritenga o te mātauranga 'hou', o te mātauranga 'mātāpuna-tini' anō hoki. Ko tā tēnei tuhinga 
he whakawātea i ngā pakiwaitara tuku nei ki tētahi whakaminenga hou, tae atu ki ngā whānau kāore i whai wāhi ki ngā kōrero nei i mua, ā, ko te āhua e tukuna ai ēnei kōrero hei akiaki pea i te whakawhanaketanga o te mātauranga mātāpunatini me te tū motuhake anō o ia o ēnei momo mātauranga.

\section{Introduction}

"What is all this?" he asked. "These are the fish I have caught," replied Titipa. "This is the result of my power as a tôhunga [priest; expert in traditional lore; person skilled in specific activity; healer]." "But didn't I tell you I should expect the pick of the catch?" cried Te Pou. "If you want fish, catch them yourself," retorted Titipa. "You don't get the pick of my haul." "Indeed," said Te Pou, and he walked along the beach and inspected the fish that were drying in the sun. "We shall see whose catch this is presently." Walking to the water's edge and stretching out his arms towards the sea, he repeated mighty spells before the people. Everyone wondered what would happen, but it was not long before Te Pou came running up the beach. "Get back!" he cried. "Get back to the high ground, or you will be drowned," and running past his people he climbed the high cliff, where he took his stand, and repeated more spells. The people, thoroughly terrified, followed helter-skelter, and left Titipa alone upon the beach. Soon the sea grew dark and troubled and angry, and presently a great wave, which gathered strength as it came, swept towards the shore. It advanced over the sandy beach, sweeping Titipa and all his fish before it, till with the noise of thunder it struck the cliff on which the people stood. "That is one," said Te Pou. "That is for the first fish. There will be two more." The great wave receded, sucking with it innumerable boulders and the helpless, struggling Titipa. Then another wave, greater than the previous one, came with tremendous force and, sweeping the shore, struck the cliff with a thunderous roar. This was followed by a third which, when it receded, left the beach scoured and bare. Titipa and all his fish had disappeared. "I have finished," said Te Pou. "That is all. There will be no more trouble ..." (The Rival Wizards: Grace, 1907a)
In 1907, Alfred Grace (1867-1942) published a series of Māori "folk stories", imparted by the Ngāti Koata ${ }^{1}$ elder Karepa Te Whetu. Within the extensive narrative of one of these stories, The Rival Wizards, the "wizard-chief", Te Pou, summoned three great waves to exact retribution upon the rival Titipa for openly defying his instructions. Descriptive details of the impact of great waves striking and scouring the beach were narrated, including many contextual details about the relationships and connections between people, place and the metaphysical world. The reciting of this narrative in print, however, did not occur again until King et al. (2007) and McFadgen (2007) cited the story, among other traditional stories, and made a case for the scientific value of Māori oral histories in understanding catastrophic saltwater inundations or tsunamis in pre-colonial Aotearoa-New Zealand (A-NZ). King and Goff (2010) surmised that the descriptive nature of the language in the story resembled those of modernday tsunami survivors and argued that it might represent an historical narrative recording direct experience with one (or multiple) tsunami inundations, prior to the arrival of the first Europeans to A-NZ in the late 18th century. However, they also acknowledged that the interpretation of Māori stories by "outsiders" is fraught with the potential for misrepresentation and concluded the need to engage with Māori who share whakapapa (ancestral and kinship linkages, genealogy, literally means "to place in layers") with specific oral histories to tell our/their own stories.

This study builds upon these collective contributions by working alongside key informants from the Māori kin groups of Ngāti Koata and Ngāti Kuia ${ }^{2}$ from the northern coast of the South Island of A-NZ (Fig. 1). These informants share linkages not only with Karepa Te Whetu but also the places and ancestral figures named in the Rival Wizards story. The paper begins by providing an overview of past work in the geosciences to have benefitted from the insights provided by indigenous oral histories. This necessarily includes a brief review of complementary lessons in political, epistemological and methodological theory. The research framing for this work and the methods of analysis are next outlined, before providing detailed accounts of the key elements of the story supported by examples of contemporary dialogue. Finally, consideration is given to the lessons, challenges and opportu-

\footnotetext{
${ }^{1} \mathrm{Ngāti} \mathrm{Koata} \mathrm{is} \mathrm{one} \mathrm{of} \mathrm{several} \mathrm{Māori} \mathrm{kin} \mathrm{groups} \mathrm{(iwi)} \mathrm{who} \mathrm{hold}$ territorial rights, power and authority associated with possession and occupation of $i w i$ land over the northern South Island (Mitchell and Mitchell, 2004). They date their occupation in the area from the late $1800 \mathrm{~s}$, and recognise the successive movements of earlier peoples migrating to and through the area. Details surrounding occupational patterns are provided in Keyes (1960) and Mitchell and Mitchell (2004).

${ }^{2} \mathrm{Ngāti} \mathrm{Kuia} \mathrm{is} \mathrm{one} \mathrm{of} \mathrm{several} \mathrm{Māori} \mathrm{kin} \mathrm{groups} \mathrm{(iwi)} \mathrm{who} \mathrm{hold}$ territorial rights, power and authority associated with possession and occupation of $i w i$ land over the northern South Island. They are often referred to as one of the ancestral $i w i$ of the region (Mitchell and Mitchell, 2004).
} 
nities that can come from bringing the knowledge-practicebelief complex of Māori Knowledge (Mātauranga Māori) together with the earth system sciences.

\section{Indigenous oral histories and tsunamis}

Consideration of Indigenous oral histories as tsunami narratives is not new. Vitaliano (1973) discussed the scientific benefits to be gained by considering "myths and legends" as transmission devices for knowledge about (and experience with) tsunamis, among other geologic phenomena. Her work detailed examples of coastal deluge attributed to tsunamis (and their likely sources) from classical Greek history through to more recent times from the Pacific coasts of the Americas to islands across the Pacific Ocean. Accordingly, Vitaliano (1973) argued that such insights provide invaluable information about extreme environmental disturbances in the pre-written past. A series of scientific contributions have since emerged from the Pacific Northwest coast of North America detailing "Indian myths" and the transmission of knowledge about great sea level disturbances (Heaton and Snavely, 1985; Clague, 1995; Hutchinson and McMillan, 1997, 2002; Ludwin et al., 2005; Ludwin and Smits, 2007; Thrush and Ludwin, 2007; Vitaliano, 2007).

Heaton and Snavely (1985) and Clague (1995) concluded that many details within indigenous oral histories are consistent with tsunami inundation processes (e.g. the sudden receding of coastal waters). Recognising this experience with earthquakes and tsunamis along the northern Washington and southern British Columbia coasts, McMillan and Hutchinson (2002) argued that oral histories can provide independent sources of information which can complement geological and archaeological knowledge about the role of infrequent yet catastrophic events in landscape evolution and socialcultural transformation. They also made explicit that such histories may have other independent meanings. Advancing this scholarship, Ludwin et al. (2005) considered 40 stories from 32 independent sources about coastal earthquakes and marine flooding, and with help from Japanese historical records they determined that the most recent large-scale event captured in multiple stories along the Cascadia coast occurred on 26 January 1700. Importantly, Thrush and Ludwin (2007) recognised not only that Native American and First Nations oral histories include rich and explicit accounts of seismic events but also that scientific inquiry is grounded in the historical relationships between indigenous and settler societies, and that this has resulted in the privileging and production of certain kinds of knowledge about the region's seismic past. Likely informed by transformative and decolonising research theories, this corollary point raised important questions about geology's relationship with colonialism, intellectual and cultural property, as well as the complex and fractious relationships between researchers and the researched. Thrush and Ludwin (2007) highlighted the tremen- dous potential for benefitting from differences in knowledge, practice and belief about some of the largest seismic events known to humankind.

Considerable scholarship has outlined the scientific value of indigenous expertise and information about tsunamis referenced in oral histories from the Pacific Islands (Nunn, 2001; Lum-Ho and Lum-Ho, 2005; Nunn and Pastorizo, 2007; Goff et al., 2008, 2011; Stewart, 2009; Johnston and Dudley, 2009) and in A-NZ (Goff et al., 2003, 2012; King et al., 2007, 2010, 2017; McFadgen, 2007; McFadgen and Goff, 2007; Pearce and Pearce, 2010; Goff and Chagué-Goff, 2015; King, 2015). Further, there are likely to be contributions from other non-English science communities about the potential value of indigenous histories enriching the geoarchaeological sciences, but such references were not identified in the sweep of English-language scholarship conducted here. Notable contributions from the Pacific include Nunn (2001), who identified ethnographic narratives of probable experiences with tsunami inundation, including a story from Pukapuka Atoll in the northern Cook Islands, where time is divided into before and after a huge wave swept over the island. Nunn and Pastorizo (2007) also identified that Pacific Islander "myths" might inform the chronology and social impacts of such hazards. Similarly, Hawaiian scholars are also re-examining their own oral histories that relate an extended history of exposure to tectonic and geologic hazards - including tsunamis (Lum-Ho and Lum-Ho, 2005; Stewart, 2009). This work is as much about adding to the scientific pool of scholarship surrounding Hawaii's tsunami risk-scape as it is about cultural revitalisation and connecting with the ancestors.

Meanwhile in A-NZ, Goff et al. (2003) emphasised the limited time frame of the historical record for understanding tsunami risk in A-NZ and thereby pointed to the Māori oral record as a potentially rich source of information about tsunamis occurring prior to European arrival. Succeeding this work, there have been varying attempts to link geoarchaeological evidence and modelling output with historical events inferred from Māori tsunami narratives (Walters et al., 2006; McFadgen and Goff, 2007; King and Goff, 2010). King et al. (2007) argued that Mātauranga Māori is a neglected area of expertise in scientific assessment and declared that greater Māori involvement is required in natural hazards science to make the most of all the knowledge and skills that Māori possess. After this, King and Goff (2010) mapped selected Māori oral histories that potentially related experience with tsunamis around the A-NZ coast. These narratives were compared with contemporary scientific data and the implications of this "new" information for tsunami science were considered. Importantly, this work signalled the need for new research approaches that openly and respectfully engage with Māori who hold ancestral and kinship linkages (i.e. whakapapa) to oral histories to tell our/their own stories. Such perspectives have the potential to amend (and perhaps replace) 

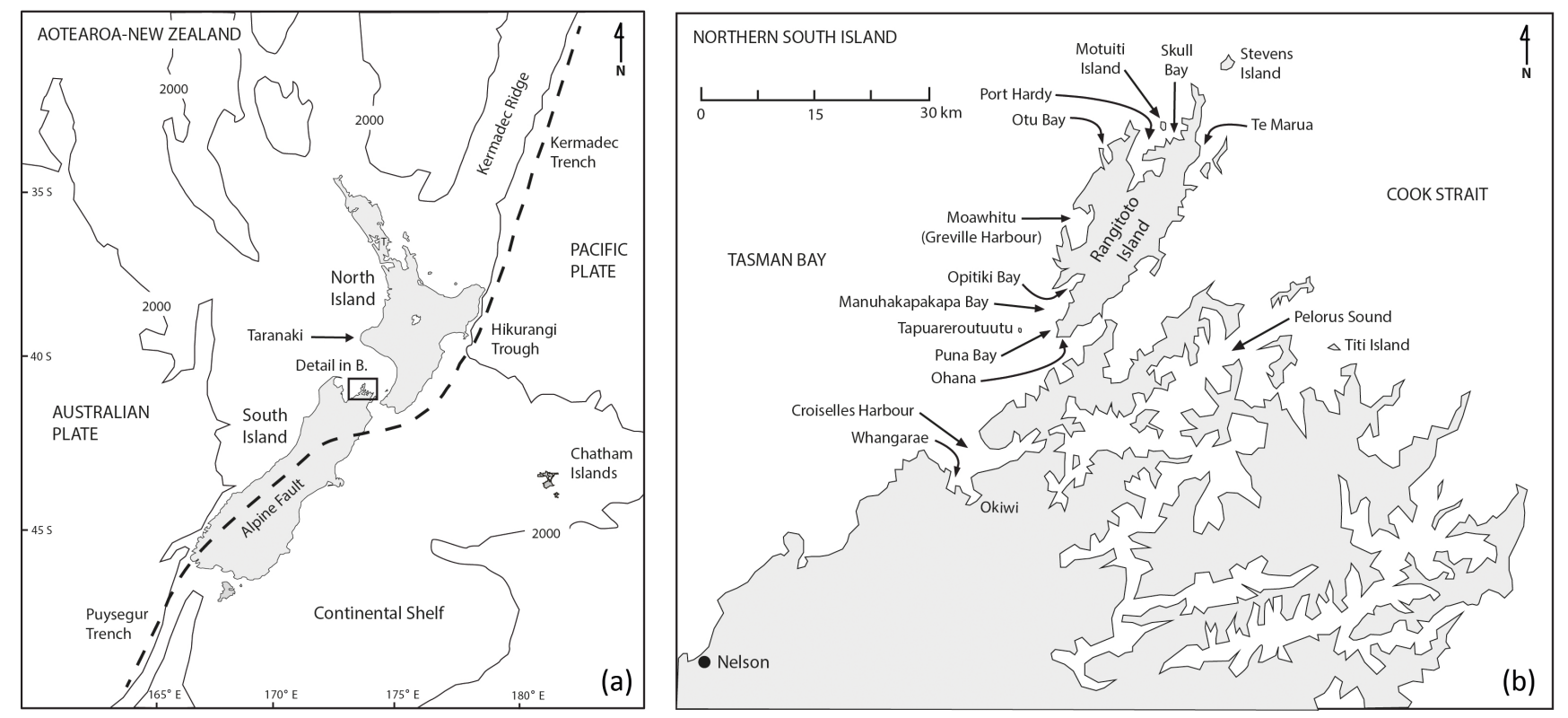

Figure 1. (a) Aotearoa-New Zealand's tectonic location in the South Pacific showing the Australian-Pacific plate boundary as a dashed line. The submerged continental shelf boundary is loosely defined by the $2000 \mathrm{~m}$ isobaths (adapted from Carter et al., 1988). (b) Rangitoto Island (D'Urville Island) and surrounding locations mentioned in the text.

accepted scientific views about pre-written tsunami disturbance and risk in A-NZ.

\section{Developments in political, epistemological and methodological theory}

Developments in political, epistemological and methodological theory from a range of disciplines are relevant to research that explores the potential of indigenous narratives to inform about environmental histories and extreme disturbances such as tsunamis. A key debate relates to how knowledge is constructed and legitimised, including whether a meaningful transfer of knowledge between different knowledge histories can occur (or alternatively do harm) when removed from its cultural context. As Mikaere (1995) argued, the outcomes of early "research" on Māori (or rather the inaccurate recordings and imaginary portrayals of narratives) rendered oral histories as "fantasy" and resulted in "epistemological disarray". Bishop and Glynn (1999) contend that this reflected the inadequacy of non-Māori to understand and accept the nature of Mātauranga Māori. Whatever the case may be, an ongoing challenge is to understand that narratives embedded within indigenous knowledge systems provide more than alternative sources of information or even alternative perspectives (Binney, 1987; Smith, 1999; Mead, 2003). Rather they have their own purposes, which may include devices that help to establish meaning for discrete and repeated events through time (Masse et al., 2007).
According to Cruickshank (1994), debates or understandings about knowledge construction are as much about "epistemology" as they are about "authorship". She explains that for many Indigenous peoples there is a reluctance to analyse and publicly explain the meanings of oral histories as this takes away from the value and different messages that come from listening to repeated tellings from family and extended kin, in place. This contrasts with a scholarly approach which encourages the scrutiny of texts, and contends that by openly addressing conflicting interpretations, meanings can be determined to enrich understanding. Many Indigenous commentators are thereby challenging researchers within the academy of science to reframe how they construct and use knowledge. This includes the treatment of Indigenous experience and knowledge as archaic and unchanging, which can, without consequence, be used by science to produce "authoritative" and "universal" insights (Howitt and Suchet-Pearson, 2003; Shaw et al., 2006; Coombes et al., 2010). In response, Johnson et al. (2016:3) argue that "scientists have to learn to see our own privilege, our own context, our own deep colonizing. We have to learn to think anew - to think in ways that take seriously and actually respond to information, understanding and knowledges as if difference confronts us with the possibility of thinking differently".

The production of knowledge is deeply entwined with power relationships and who holds control and authority over knowledge and its applications (Stephenson and Moller, 2009). This challenge is based on the premise that power underpins the place of science in contemporary society, and that 
the narrators of science (and history) ultimately hold power, whether knowingly or not (Johnson et al., 2016). Indigenous commentators (and others) have discussed legacies of extractive research practice, whereby non-Indigenous researchers have treated the holders of Indigenous knowledge as if they have no moral or legal rights to decide how it will be represented or used within the wider world. Such practices have often resulted in leaving those studied disenfranchised from the knowledge they have shared (Kovach, 2009). Indigenous scholars have thereby mounted a critique of the way history has been told from the perspective of the colonisers - and this has resulted in debates over who gets to frame and legitimise knowledge, whose voices are prominent in these discussions, and for whom the writing is being done (Smith, 1999). A number of scholars have also challenged the notion of including "voices" in projects that aim to speak (or write) on behalf of "others" (Howett and Suchet-Pearson, 2003). For example, Coombes et al. (2014:849) argue that "research that took the once-radical step of 'giving voice' now patronizes and silences those whose voice is quite capable of self-expression". While we recognise as researchers and authors the contradiction in the work completed here, we acknowledge at the same time the collaborative basis of the research and the contribution such grounded histories provide to scholarship.

In response to these histories and ethical challenges, all of which are taking place against a broader background of indigenous self-determination and cultural affirmation, there is increasing recognition of "decolonising" and "countercolonial" research methodologies that seek to reframe and transform the way research and knowledge is produced (Smith, 1999; Mead, 2003; Kovach, 2009). Key elements of this discourse (although not limited to) include (i) valuing not only specific forms of Indigenous knowledge but also the values underpinning such systems, (ii) recognising the authority of Indigenous peoples to determine the rules for producing new knowledge, (iii) safeguarding the authenticity of indigenous narratives, (iv) supporting research that enriches everyone who is connected with the research project, and (v) promoting the benefits that come from learning from different ways of being and knowing. Howitt and SuchetPearson (2003:559) remind us also that "choosing whom to include and how to include them, the choices other people have made in representing themselves to the author and other authors, the ways the readers interpret the words and the ulterior motive for the usage of the 'voices', all involve relationships of power".

\section{Research framing}

\subsection{Methodological approaches}

This research applies an inductive-based methodological approach informed by "collaborative storytelling" to consider the meaning and memorials presented in the Rival Wizards narrative. The methodology does not fit neatly into any category, but draws on decolonising research approaches (Smith, 1999; Kovach, 2009) and grounded theoretical principles (Glaser and Strauss, 1967; Pidgeon, 1996), while simultaneously seeking plural spaces of learning (Howitt and SuchetPearson, 2003; Zanotti and Palomino-Schalsha, 2006; Johnson et al., 2016). This theoretical framing was underpinned by Kaupapa Māori research principles (Smith, 1990, 1999; Te Awekotuku, 1991; Mead, 2003). All informants were assured of their right to maintain authority over their contributions by reviewing, editing and approving the "new" narrative produced through this work. The National Institute of Water and Atmospheric Research (HREC2017-005) and the University of New South Wales (HREC-17085) provided human research ethics approvals.

\subsection{Methods, analysis and interpretation}

Semi-directive individual and paired interviews with 20 key informants from Ngāti Koata and Ngāti Kuia were used to discuss the construction, key elements and purposes of the Rival Wizards narrative. In advance of all interviews a copy of the Rival Wizards story (Grace, 1907a) was provided to all informants from Ngāti Koata and Ngāti Kuia. Interview participants self-selected and/or were recommended by participants and extended family members. Each session lasted between 0.5 and $2 \mathrm{~h}$ and was attended by a research facilitator. All interviews were electronically recorded. Analysis of interview material was inductive and consisted of (i) "content analysis" whereby ideas or words were identified along with the frequency of their use, (ii) "thematic analysis" whereby the principal elements emerging from the data were examined and sorted, and (iii) cross-checking the integrity of emergent ideas and interpretations through follow-up discussions with key informants with adjustments made where necessary. Central to these analyses was an emphasis on participant views about the narrative (rather than the meaning the researchers brought to the research). Secondary sources of information provided supplemental support. In following such methods, we sought to avoid subjecting the story to external judgements or, in other words, risk turning the story into something it is not.

\section{The Rival Wizards (abridged)}

An abridged version of the Rival Wizards story is outlined below to provide context for the summarised commentaries that follow. Importantly, in abridging the story, we are mindful that where one chooses to begin and end a story can alter its shape and meaning, and so we encourage a reading of the full story as published by Grace (1907a). 


\subsection{Synopsis of the story}

The story begins with Rongomai, a "wizard-chief" renowned for being able to shape-shift from monstrous to human form. One day, with his revered greenstone fish-hook (named Huakai after one of his most famous ancestors) Rongomai paddled from his island settlement of Motiti to the shore of the mainland opposite the settlement of Motu to fish for $h a-$ puku (wreckfish) and kahawai (A-NZ salmon). Boastful of his prowess as a fisherman Rongomai soon lost Huakai to a large fish, leaving him miserable and despairing. Te Pou, the rival "wizard-chief" from Motu, watched these proceedings from the shore. Famed also for his shapeshifting capabilities, Te Pou waited until after dark and then stepped into the water, turning himself into a shark, and searched for the coveted hook. However, Rongomai initiated an immense fishing haul, and relocated "Huakai", although there was consternation at a large hole in one of his nets presumably caused by a shark. Te Pou was furious at Rongomai for having found "Huakai", and for almost having been caught in his fishing nets. Vowing revenge, Te Pou later swam to the village of Motiti, and in the middle of night he thrust a burning stick into the thatch of Rongomai's house. Rongomai's human form was burnt and he was thereafter confined to an aquatic existence as a veracious and malevolent salmon. The fish from the coast near Motu were soon thereafter driven away by Rongomai, and then while swimming, Te Pou's son, Kopara, was eaten by Rongomai. The mourning Te Pou subsequently planned a great farewell for his son, but realising the scarcity of fish he transformed himself into a porpoise and travelled to have an audience with Tangaroa, the supreme ruler of the sea. Here Te Pou requested that all the salmon over whom Tangaroa held sway be summoned to Motu, to the mouth of the river, to weep for his son. Tangaroa agreed to the request, but also indicated his interest in joining the occasion. In reply Te Pou acknowledged the great pleasure this would bring, but he cautioned that the water at Motu is hardly deep enough, with extensive mudflats and the river so shallow that it would be a most inconvenient place for Tangaroa. Returning home Te Pou advised his people to prepare their nets for the fish that would come, advising that he expected the pick of three fish for his own use. Standing on the shore Te Pou proceeded to say incantations, while Titipa, the next chief in command and secret rival, ignored Te Pou's requests. When the great haul of fish was pulled ashore, Te Pou returned to inspect the catch only to find Titipa claiming it. Te Pou therein warned all to stand back from the beach as three great waves were called forth, advancing and receding from the beach, eventually taking Titipa with them. The story ends with Te Pou selecting the three largest fish from the collective haul, gifting the first to his son and the sea, the second to his wife, and the third for himself, ending Rongomai's existence.

\section{Storytelling through whakapapa}

\subsection{Narrative sources}

The published version of the Rival Wizards story (Grace, 1907a) was "not known" by the informants from Ngāti Koata and Ngāti Kuia prior to the formal discussions carried out for this study. There were, however, many repeated qualifications about parts of the narrative being very familiar. Independent of one another, informants from both kin groups initially expressed "I am not familiar with the story", "The story does not ring a bell for me", "I've never heard our people talk about it" and, among others, "The first time you gave me the story is the first time I had come across this". There was, however, widespread awareness of Karepa Te Whetu (the informant of the story), first by the research participants from Ngāti Koata who hold direct genealogical connections, and second by those from Ngāti Kuia who recognised his name from pan-tribal history. From these collective voices, we know that Karepa Te Whetu lived on D'Urville Island (Rangitoto) and that he was the elder son of Te Whetu, a respected Ngāti Koata leader who migrated with other Ngāti Koata descendants from the North Island in the 1820s to settle on Rangitoto and other areas across the northern South Island (Fig. 1). Te Whetu had a settlement at Te Marua (northeastern side of Rangitoto), which is known for its swampy ground and cliffs. An informant suggested that Karepa Te Whetu most likely grew up at Te Marua alongside kin from Ngāti Koata and the already occupying people of Ngāti Kuia. For example, an informant from Ngāti Koata reflected, "Ngāti Koata moved down here in the 1820s. And there was a whole big history on that island [Rangitoto] before we moved in so I wonder how much of that history, those stories, that he [Karepa Te Whetu] heard". In his later years, it was widely understood that Karepa moved to Croiselles Harbour, where he spent his final days (although one informant suggested that he may also have lived at Taranaki for a while). According to Grace (1907b) it was during this period that he got to know Karepa Te Whetu, leading eventually to the sharing of numerous stories, until Karepa's death in 1903.

Reflecting further upon the Rival Wizards story shared by Karepa Te Whetu with Alfred Grace, many informants from Ngāti Koata and Ngāti Kuia noted that knowledge holders had probably passed on and/or moved away from the island, thereby taking many of their stories with them. One informant also remarked, "Some of our old people were cautious about who they told things to, so they never told them". Other explanations for not knowing the Rival Wizards story included reference to changes in the resident population of Rangitoto following the arrival of the first Ngāti Koata peoples and thereafter the broader social-cultural changes stemming from the arrival of the first missionaries. Statements from both Ngāti Koata and Ngāti Kuia informants included "What happened prior to the heke [migration] ... there are a lot that probably won't know what those stories were ... 
so yeah it is probably a Ngāti Kuia story", "These events [in the story] are before Ngāti Koata. It's probably a Ngāti Kuia story eh?" and "Ngāti Kuia lived on the Island, right up until the 1870 s, early 1880 s. My great grandfather was born on the island [Rangitoto] but he was straight Kuia ... And then all the Kuia left ... so lots of those korero [stories] about Rangitoto were not spoken about anymore. Ngāti Kuia lost a lot of those korero whereas our Ngāti Koata-Kuia relations who stayed on the island retained their knowledge of the place". Whatever the case might be, two informants (one from Ngāti Koata and the other who recognised their links to both Ngāti Koata and Ngāti Kuia) also affirmed that they had no reason to doubt the story from Karepa Te Whetu: "If it [the story] came from Karepa, I have no reason to doubt it". Finally, upon questioning the informants about the role of Alfred Grace in the telling of the story there was no mention of misgiving or distrust, as is common for other Māori when reflecting on the work of other ethnographers of the time (Mikaere, 1995; Smith, 1999; Haami, 2012).

\subsection{Key elements and storytelling devices}

Many of the informants expressed familiarity with the places and contextual details described in Grace's account. The most common reflections included reference to the two settlements named in the story, Motiti and Motu. Initial discussions suggested informants were unaware of such settlement names on, or surrounding, Rangitoto. However, several informants from Ngāti Koata and Ngāti Kuia (in conversations independent of one another) were quick to point out that there is a Motuiti Island, also known as Moutiti, Motiti and Victory Island, just off the northern coast of Rangitoto (Fig. 1). For example, one Ngāti Kuia informant stated, "In the old books, it is referred to as Motiti and Moutiti. Motiti - that could be just a misspelling if it has been orally translated. That kind of thing was prevalent when they [ethnographers] were transcribing as they heard it and I would expect it would have been the same kind of situation here ... Motiti, Moutiti, Motuiti”. However, one Ngāti Koata informant questioned these possible linkages, drawing specific attention to there being no beaches on Motuiti and no visible signs of having been occupied (i.e. pits or middens). Notwithstanding these literal inconsistencies, the same informant described the island as an important site for ongoing traditional harvesting of wild foods.

With reference to the settlement of Motu, one Ngāti Kuia informant noted the proximity of Motuiti Island to the historical settlement at Otu Bay at the northern end of Rangitoto, and questioned whether Otu Bay might be a misspelling of Motu (Fig. 1). Another Ngāti Kuia informant questioned whether Motu might be a shortening of a longer name such as Motungararara (now formally named Titi Island), which was not only the site of a settlement held by Te Pou Whakarewarewa (an historical figure understood to have lived during the late 18th century) but also a position where he had control of all the area. It was surmised by another informant from Ngāti Koata that by using the name Motu (which translates as "Island") Karepa Te Whetu may have been "generically" referring to all the islands in the area, not just a specific place. Alternatively, another informant from Ngāti Koata offered that "just because people don't know this name 'motu' it doesn't mean that there wasn't a place called motu, but the name may have been buried or usurped by new peoples coming in ...". Given these initial commentaries, there was general agreement that the story was derived from (and/or around) Rangitoto, but it was not possible to confirm any specific location.

The description of extensive mudflats and a shallow river at the settlement of Motu also led some informants to specifically reflect on several locations on Rangitoto and its surrounds with similar physical characteristics. For example, a Ngāti Koata informant stated, "When I think about that, I think about Whangarae on the Nelson mainland, just before Okiwi Bay. It was closer than other places on the Island. My recollection is going there as a child for a tangi [funeral] and we anchored our boat out there and on the low tide it was stranded. We just waited for the tide to come back in again. And there was a big settlement in that place ... at Whangarae ... That area is still owned by Ngāti Koata. Not many people live there now but there are a lot of owners ... you could class that as part of D'Urville Island [Rangitoto]" (Fig. 1). The same informant emphasised that these places were not regarded as separate by the people living in these areas and that any attempts to locate places referred to in the story need to understand that the sea connected all the islands and the mainland as well as the settlements situated along their coasts. The informant added, "There is another place on D'Urville Island which is in the Manuhakapakapa Bay. The water there and particularly Opitiki Bay was heavily populated pre-Ngāti Koata and probably even Ngāti Kuia ... and the water there is shallow".

Specific reference to a "river" at Motu also led some informants to contemplate the absence of rivers on the island as well as the neighbouring mainland. While this was inexplicable for some, informants from both Ngāti Koata and Kuia recounted that the extensive use of geomorphic names such as "sounds" and "arms" across the northern South Island today refer to locations that were traditionally referred to as awa (river). For example, "Te Hoiere - is a good example of that. Today we talk about the Pelorus River and Pelorus Sound, as opposed to Te Hoiere being one big entity into the Cook Strait. Even some of the place names through the sounds Awaiti and Awanui, they were calling arms at the time also, so even if we were thinking about D'Urville Island and Port Hardy and Greville Harbour and all of those places, there are lots and lots of little arms all over the place [that would have had names]" (Fig. 1). Such contextual nomenclature may thereby explain the use of the term "river" in the story. 
Ancestral protagonists were another common element discussed by all informants. However, it is important to qualify that most key informants from Ngāti Koata either declared no knowledge of the names or that the names (or at least some) pre-dated the arrival of Ngâti Koata people to the region. In contrast, most of the key informants from Ngāti Kuia recognised the names of the central protagonists, and quickly confirmed linkages, citing genealogical books and historical transcripts (e.g. Meihana Whakapapa Book, no date; Hemi Whakapapa Book, no date), and the ongoing use of such names today. As one respondent declared, "Rongomai, Te Pou and Titipa - I know all those names" and another stated, "Te Pou - yep that's my father's middle name. Te Pou is a very common name for Ngāti Kuia. Every Peter is a Pou ... so that name's a common one". Another said, "Te Pou and Rongomai have been commemorated down to the present day by the repeated use of their names in the lines of Ngāti Kuia whānau [families]". The sacred fishing hook "Huakai" used by Rongomai was recognised by another Ngāti Kuia informant as a term used by recent generations of Ngāti Kuia. It was also noted that the ancestors named in the story also derived from quite different periods of time. Thereby, any attempts to historicise elements within the story based on genealogy would more likely than not result in looking for detail that is not there. Two commentaries summarise these sentiments: "Such stories were not necessary told in a linear fashion" and "The stories don't follow linear ways of telling a story and that is important because you can have different ancestors from different times to celebrate those people, to remember them, to remember a lesson ... so they are not forgotten". In this way, it is the protagonists rather than chronological dimensions of time that are of most relevance.

Other contextual aspects in the story considered relevant to connecting the narrative to the Rangitoto (D'Urville Island) area included the multiple references to large (lamniform) sharks and kahawai (salmon). Many of the informants from Ngāti Koata who grew up on Rangitoto described deep familiarity with large sharks and kahawai (salmon) in the area, particularly at Manuhakapakapa Harbour (Fig. 1). For example, "Kahawai were plentiful around the Island [Rangitoto] ... like at Kape [Manuhakapakapa Bay] ... there was a big käinga [settlement] there" and "Kahawai is everywhere, we get it quite easy ...". Notwithstanding that $k a$ hawai and lamniform varieties of shark are common around A-NZ coastal waters (Roberts et al., 2015a, 2015b), some informants queried whether there may be linkages between locations well known for their shark and kahawai abundance around the island and the traditional settlement of Motu named in the story. Manuhakapakapa Harbour, Whangarae, Otu Bay and Skull Bay in Port Hardy were all identified as possible analogue sites given the significant settlements that once existed at all of these neighbouring places. While such information alone was recognised as insufficient to draw any firm conclusions about the specific location for the story, many informants nonetheless regarded the multiple layers of contextual information in the story as highly relevant for connecting the story to the Rangitoto (D'Urville Island) area. As one of the informants from Ngāti Kuia summarised, "It is not only the descriptive language of catastrophic waves being called ashore, but the other details, that make us believe we are in the place".

Finally, references to the power of prayer and incantation (karakia) as well as shapeshifting (turehu) in the story were identified as also highly relevant to any claims of the narrative coming from the northern South Island. Ngāti Kuia informants emphasised not only this power but also the reputation held by the "tōhunga" (priest; expert in traditional lore; person skilled in specific activity; healer) of Ngāti Kuia to modify the elements. For example, "We were known as te iwi karakia [the necromancing people] ... but not the kind that do makutu [dark incantations]. Our karakia were very much a demand, that was the mana [authority, control, influence, prestige] and power of the tōhunga [priest; expert in traditional lore; person skilled in specific activity; healer]. We are connected to all of our Atua [Gods, deity] and we are made of our Atua". These discussions also led one of the informants from Ngāti Kuia to reflect specifically on the significance of the incantation used in the story and whether the description of destructive waves was due to a tsunami or a phenomenon manifest through metaphysical forces. In response, the informant answered, "What I do know is that our people were recognised as very strong kaikarakia [necromancers]". Mitchell and Mitchell (2004) have also pointed out that Ngāti Kuia have long been recognised for their powers in this regard and historical transcripts are known to contain karakia about how to control the sea and the waves, with many references to Rangitoto (Smith, 1889). The story also incorporates multiple references to Te Pou and Rongomai "shapeshifting" or transforming themselves into various life forms from the sea, from whale and shark to porpoise and $\mathrm{ka}$ hawai. Again, several informants from Ngāti Kuia affirmed a deep familiarity with such details, including acceptance of the supernatural and the metaphysical world. For example, "Shapeshifting, that is acceptable to me. I grew up with that korero [story]" and "Kaikaiawaro is our kaitiaki [person, group, being that acts as a carer, guardian, protector and conserver] and he takes the form of a dolphin". Further still, the familiarity with these elements in the story extended to recognition among many of the Ngāti Kuia informants that they were descendants of Kaikaiawaro, and that he is present in their genealogy as an ancestor rather than an Atua. As an informant declared, "Yes ... when I was reading that Te Pou goes to visit Tangaroa and he transforms himself, it was like, we know that because Kaikaiawaro, who is in our whakapapa as a person, could manifest himself as a dolphin ... We are the descendants of Kaikaiawaro". 


\subsection{Memorials and analogue stories}

Reflecting upon the specific narrative of Te Pou (the principal protagonist in the Rival Wizards story) calling forth catastrophic waves, many informants from Ngāti Koata and Ngāti Kuia regarded this account as most likely referencing direct experience with past tsunami inundation. However, almost all of these informants openly acknowledged that they did not know where this story occurred and/or when it happened, and that the narrative was being told within a framework of deities and supernatural humans with influence over the elements. Consideration of the narrative as a tsunami tradition also led several of the informants to note similarities with the destructive waves described in another story from Moawhitu (Greville Harbour) on the western side of Rangitoto (Fig. 1). According to these commentaries a tsunami, possibly occurring in the 1400 s or 1500 s, drowned nearly all people living around Greville Harbour, and their bodies now lie in the surrounding sand dunes. For example, "Yes, there was a great big tidal wave. I heard it when I was a kid. My grandmother told me when I was a child. This story is tuturu tika [genuinely truthful]. I don't question it". The story of Moawhitu was also recounted by Karepa Te Whetu to Elsdon Best and published in the Journal of the Polynesian Society in 1893 (Best, 1893). It describes the people of Ngai-Tarapounamu who settled Rangitoto Island and a breach of tapu (sacrosanct, forbidden, inviolable) by a local woman which led to the gods stirring up the deep ocean and causing great waves to sweep away people where the woman was living. Phillipson (1995) purports that the "tidal wave" occurred some time in the 16th century, while Cope (2011), Chagué-Goff and Goff (2012a, b) and Cope et al. (2012) indicate the previous century as more likely based upon the inferred timing of a Māori occupation layer beneath marine gravels at Moawhitu as well as palaeotsunami evidence from neighbouring sites across region. Meanwhile, Mitchell and Mitchell (2004) referred to the "tidal wave" as Tapu-arero-utuutu (vengeance for the breaking of strict food preparation practice) and postulated that the people already living on the island prior to the arrival of the kin group Ngai-Tarapounamu may have been from the ancient Waitaha peoples and/or early Ngāti Kuia lines. It is also noteworthy that one informant familiar with the name Tapu-arero-utuutu identified a stand of offshore rocks to the south-west of Rangitoto by the same name (Fig. 1). The association of this name with tsunamis and its close location to Rangitoto were, however, not mentioned.

More than one informant questioned whether the Rival Wizards narrative might be a retelling of the Moawhitu tradition. One informant questioned where knowledge of the Moawhitu tradition had actually come from. For example, "I have heard the korero about Moawhitu and the tsunami there, but I was told by my uncle (and he is passed away now) that the people were labouring men but also avid readers so I cannot say whether that story was one that we had or what he had read and then became ours". Meanwhile another informant reflected that the (Rival Wizards) story might not necessarily be referring to Moawhitu, but rather the Manuhakapakapa area due to the strong references to kahawai and the abundance of people in the area: "This certainly could have been a place where that korero might have been had". In contrast, Otu Bay and Skull Bay were also identified by other informants as equally likely sites referenced in the story. As noted earlier, one Ngāti Koata informant reflected that the name motu might have been used not only in a general sense but also to reflect that there are many places here that were likely affected by the extraordinary waves described in the story, and so a generic settlement name was used to capture this. Whatever the case may be, in considering the specific sites and sources for the Rival Wizards story there was widespread agreement (although not total) that the story and its elements derived from Rangitoto and the connected places and peoples that surround the northern South Island. As one respondent noted, "It's definitely got the feel that it comes from this place".

\section{Māori oral histories and natural hazards science}

\subsection{Lessons and opportunities}

By engaging directly with informants from Ngāti Koata and Ngāti Kuia it is evident that there is a deep familiarity with the different elements contained in the Rival Wizards story. This includes knowledge of past tsunami impacts on, and surrounding, the island of Rangitoto. Dialogue may not have included familiarity with the specific story itself, but ancestral relationships were confirmed between informants of Ngāti Koata descent and the original informant of the story Karepa Te Whetu as well as those informants of Ngāti Kuia descent and the leading protagonists in the story. Many other aspects of the story are also deeply rooted in the enduring knowledge of Māori histories across the northern South Island. While such information is insufficient to draw any firm conclusions about a specific location for the occurrence of catastrophic waves, these oral histories from Ngāti Koata and Ngāti Kuia provide strong collective evidence for pre-written tsunami inundation(s) on Rangitoto Island and the neighbouring coast.

More broadly, this work confirms that Māori oral histories are dynamic, even when committed to writing in an ethnographical text. The Rival Wizards story holds multiple purposes comprising elements of culture, place, identity, lineage, history and, in this case, environmental risk. It is also clear that ancestral and kinship linkages to people and place (i.e. whakapapa) are central to the construction and ongoing retelling of Māori histories. Royal (1992:21) affirmed this notion stating that whakapapa is "the fabric upon which tribal histories sit", generating meaning for human behaviours and understanding in the Māori tribal world. Further, Roberts (2012) explained that whakapapa is used in storytelling as a construct for mapping the natural world and its 
phenomena, thereby acting as a "mental map" of place. And, most recently, Kelly (2016) has reflected that Māori knowledge was stored layer by layer, referencing places, ancestors and the actions of protagonists as "memory cues" to retain vitally important information. The specific layering of contextual detail in the Rival Wizards story affirms these connections and relationships between the natural and metaphysical worlds, including the narrative structures critical to cultural endurance and memory.

Our working with informants from Ngāti Koata and Ngāti Kuia also highlights that Māori oral histories can complicate scientific definitions of what constitutes events. That is, the earth sciences typically treat events as discrete and bounded, but in the case of The Rival Wizards a different paradigm with non-linear contextual details is used to establish layers of meaning with ancestral protagonists from different epochs of genealogical time. Tau (1999) reflects that events in the Māori world are often recalled relative to known ancestors rather than fixed at some objective point in time. Further, he points out that trying to apply chronology to genealogical time is akin to historicising a past that was not intended to constitute a linear history. In short, Mātauranga Māori orders itself differently, and thereby the risk of misinterpretation is high when stories and their elements are not understood within the context of ancestry and cultural experience (Roberts and Wills, 1998; King and Goff, 2010sss).

The methodology underpinning this research provides an example of how the earth system sciences as well as the knowledge-practice-belief complex of Mātauranga Māori can benefit from engaging collaboratively with one another. Confirmation of deep connections to the Rival Wizards story and subsequent affirmation of ancestral experience with past tsunami(s) across the northern South Island casts off earlier assumptions that the story might derive from the eastern Bay of Plenty (King and Goff, 2010). Further, this study emphasises the value of such engagements, particularly for scientific researchers who seek to learn from the historical experience captured in Māori oral histories. From this epistemological position, we agree with Styres (2008), who argued that the challenge for researchers from the academy of science is to go beyond traditional methodological approaches and assumptions about research which select and frame stories from the point of view of the dominant culture. Further, we concur with Johnson et al. (2016:3) that a reframing of science is needed whereby "one is drawn to the wider value of a dialogue across knowledge systems that is humble, respectful and hopeful; which recognizes not only the need to acquire knowledge, but also the need to transform and respond to different knowledges, understandings, meanings, and opportunity". However, we simultaneously acknowledge that this is deeply challenging because the research structures around us constantly push and pull us to neglect and compromise these values, ethics and practices. Further, we recognise that research framing will not solve all the problems associ- ated with the hierarchies of power and knowledge production (Mustonen, 2014).

Notwithstanding these ongoing tensions, engaging in this work can help to promote "plural spaces" of learning that contribute to the reclaiming of stories and culture as well as the development of new knowledge and new questions (Howitt and Suchet-Pearson, 2003; Zanotti and PalominoSchalsha, 2006). For example, this study contributes to a number of projects currently being undertaken by Ngāti Koata and Ngāti Kuia by adding to their existing stores of socio-cultural knowledge and history. This research space also provides an opportunity for the knowledge-practicebelief complex of Mātauranga Māori to engage with the academy of science about tsunami disturbance, recurrence and risk. And, as already articulated, there remain many unrealised opportunities for Mātauranga Māori to inform the earth system sciences about extreme hazard episodes and risk along the A-NZ coastline over the past 1000 years (King and Goff, 2010; King, 2015; King et al., 2017). Such work, however, will require greater attentiveness to relationships among people involved in the research, including the need to be aware of contemporary developments in political, epistemological and methodological practice.

\section{Conclusions}

Working alongside key informants from the Māori kin groups of Ngāti Koata and Ngāti Kuia this work confirms Māori ancestral experience with a past tsunami, possibly multiple events, on, and surrounding, Rangitoto (D'Urville Island). While it is not possible to draw any firm conclusions about a specific location for the occurrence of past "catastrophic waves", it is evident that Māori oral histories are highly contextual and purposeful, comprising multiple layers of meaning and experience. Further, to engage with such histories (and the people who link genealogically to such stories) requires close attention to a politics of representation of those stories, in both past recordings and current ways of retelling, as well as sensitivities concerning how knowledge is constructed, distributed and applied. If the geosciences are to advance scholarship that promotes plural knowledge development (and plural knowledge co-existence), then a commitment to the acquisition of new skills in trans-cultural research enquiry will be required. The potential of such work to contribute to the production of "new" narratives about tsunami disturbance, recurrence and risk around the A-NZ coast is regarded as high.

Data availability. All relevant data are within the paper. Any additional raw data not directly used in this paper can be obtained by contacting Darren N. King: darren.king@niwa.co.nz. 
Competing interests. The authors declare that they have no conflict of interest.

Acknowledgements. The authors wish to acknowledge the key informants from Ngāti Koata and Ngāti Kuia, without whom this work could not have been undertaken. Mere Roberts and Bruce McFadgen are thanked for their constructive review comments, and Stephanie Huriana Martin is acknowledged for her assistance with Te Reo Māori. We also acknowledge Michael Crozier and Walter Dudley for their constructive comments on an earlier version of the manuscript. This research was funded by the Resilience National Science Challenge - Vision Mātauranga (grant agreement no. 28378) and the NIWA Strategic Science Investment Fund - Hazards, Climate and Māori Society (grant agreement no. C01X1702).

Edited by: Thomas Glade

Reviewed by: Walter Dudley and Michael Crozier

\section{References}

Best, E.: Te Patunga o Ngarara-Huarau: How Ngarara-Huarau was killed, The J. Polynesian Soc., 2, 211-219, 1893.

Binney, J.: Maori oral narratives Pakeha written texts: two forms of telling history, New Zeal. J. Hist., 21, 16-28, 1987.

Bishop, R. and Glynn, T.: Culture counts: Changing power relations in education, Dunmore Press, Palmerston North, New Zealand, 233 pp., 1999.

Carter, L., Lewis, K. B., and Davey, F.: Faults in Cook Strait and their bearing on the structure of central New Zealand, New Zeal. J. Geol. Geop., 31, 431-446, 1988.

Chagué-Goff, C. and Goff, J.: A record of short- and long-term environmental changes at Moawhitu Wetland, Rangitoto ki te Tonga (D'Urville Island) - What we know so far. Moawhitu Newsletter (D'Urville Island) DOC permit NM-22329-GEO, 27 February 2012.

Chagué-Goff, C., Cope, J., Goff, J., McFadgen, B., Mooney, S., Kilroy, C., Zawadzki, A., Wong, H., and Jacobsen, G.: Return of the Sea Monster - a tale from D'Urville Island, New Zealand, Abstract, Proceedings of the third Joint IGCP588/INQUA 1001 Meeting "Preparing for Coastal Change", Kiel, Germany, 4-10 September 2012, p. 47, 2012.

Clague, J.: Early Historical and Ethnographical Accounts of Large Earthquakes and Tsunamis on Western Vancouver Island, British Columbia, in: Cordillera and Pacific Margin/Cordillère et marge du Pacifique; Geological Survey of Canada, Current Research no. 1995-A, 47-50, 1995.

Coombes, B., Gombay, N., Johnson, J. T., and Shaw, W. S.: The Challenges of and from indigenous geographies: Implications for openly transcultural research, in: A Companion to Social Geography, edited by: Del Casino, V. J., Thomas, M., Cloke, P., and Panelli, R., Blackwell, Oxford, 472-489, 2010.

Coombes, B., Johnson, J., and Howitt, R.: Indigenous geographies III: Methodological innovation and the unsettling of participatory research, Prog. Hum. Geog., 38, 845-854, 2014.

Cope, J.: Holocene sedimentary record of gradual, catastrophic and human influenced environmental changes at Moawhitu Wetland,
D’Urville Island, New Zealand, Unpublished Honours Thesis, University of New South Wales, Sydney, Australia, 2011.

Cope, J., Chagué-Goff, C, Mooney, S., Goff, J., Zawadzki, A., Wong, H., Kilroy, C., Jacobsen, G., and Dominey-Howes, D.: Holocene record of gradual, catastrophic and human influenced environmental change at Moawhitu wetland, D’Urville Island, New Zealand. Proceedings of the AMOS Annual Conference 2012: Connections in the Climate System, Sydney, Australia, 31 January-3 February, Abstract, p. 226, 2012.

Cruickshank, J.: Oral Tradition and Oral History: Reviewing Some Issues, Canadian History Review, 75, 403-418, 1994.

Glaser, B. G. and Strauss, A. L.: The discovery of grounded theory: Strategies for qualitative research, 271 pp., Aldine Press, Chicago, USA, 1967.

Goff, J. and Chagué-Goff, C.: Three large tsunamis on the nonsubduction, western side of New Zealand over the past 700 years, Mar. Geol., 363, 243-260, 2015.

Goff, J., Hulme, K., and McFadgen, B. G.: Mystic Fires of Tamaatea: Attempts to creatively rewrite New Zealand's cultural and tectonic past, J. Roy. Soc. New Zeal., 33, 1-15, 2003.

Goff, J., Charley, D., Haruel, C., and Bonté-Grapentin, M.: Preliminary Findings of the Geological Evidence and Oral History of Tsunamis in Vanuatu, SOPAC Technical Report No.416, Suva, Fiji, 2008.

Goff, J., Chagué-Goff, C., Dominey-Howes, D., McAdoo, B., Cronin, S., Bonté-Grapetin, M., Nichol, S., Horrocks, M., Cisternas, M., Lamarche, G., Pelletier, B., Jaffe, B., and Dudley, W.: Palaeotsunamis in the Pacific, Earth-Sci. Rev., 107, 141-146, 2011.

Goff, J., Chagué-Goff, C., Nichol, S. L., Jaffe, B., and DomineyHowes, D.: Progress in palaeotsunami research, Sediment. Geol., 243-244, 70-88, 2012.

Grace, A.: Folktales of the Maori, Gordon \& Gotch, Wellington, 1907a.

Grace, A.: News item: Folk tales of the Maori, Grace describes Karepa Te Whetu, Marlborough Express, Volume XLI, Issue 279, Tuesday 26 November 1907, 1907b.

Haami, B.: Ta te ao Maori: writing the Maori world, in: Huia histories of Māori: Ngā Tāhuhu Kōrero, edited by: Keenan, D., Huia Publishing, Wellington, 2012.

Heaton, T. H. and Snavely Jr., P. D.: Possible Tsunami along the North-western Coast of the United States Inferred from Indian Traditions, Bulletin of the Seismological Society of America, 75, 1445-1460, 1985.

Hemi Whakapapa Book: Copies held in Ngati Kuia Archives, Te Rūnanga O Ngāti Kuia, Nelson, New Zealand, no date.

Howitt, R. and Suchet-Pearson, S.: Ontological pluralism in contested cultural landscapes, in: Handbook of cultural geography, edited by: Anderson, K., Domosh, M., Pile, S., and Thrift, N., SAGE Publisher, London, 557-569, 2003.

Hutchinson, I. and McMillian, A. D.: Archaeological Evidence for Village Abandonment Associated with Late Holocene Earthquakes at the Northern Cascadia Subduction Zone, Quaternary Res., 48, 79-87, 1997.

Johnson, J., Howitt, R., Cajete, G., Berkes, F., Louis, R. P., and Kliskey, A.: Weaving Indigenous and sustainability sciences to diversify our methods, Sustain. Sci., 11, 1-11, 2016. 
Johnston, J. and Dudley, W.: Pacific Island Tsunami Resilience Planning Guide, National Oceanic and Atmospheric Administration, Pacific Services Center, Honolulu, Hawai'i, 2009.

Kelly, L.: The Memory Code, Allen and Unwin, 336 pp., Australia, 2016.

Keyes, I. W.: The cultural succession and ethnographic features of D’Urville Island, J. Polynesian Soc., 69, 239-265, 1960.

King, D. N.: Tsunami hazard, assessment and risk in Aotearoa-New Zealand: A systematic review, Earth Sci. Rev., 145, 25-42, 2015.

King, D. N. and Goff, J. R.: Benefitting from differences in knowledge, practice and belief: Māori oral traditions and natural hazards science, Nat. Hazards Earth Syst. Sci., 10, 1927-1940, https://doi.org/10.5194/nhess-10-1927-2010, 2010.

King, D. N., Goff, J., and Skipper, A.: Māori Environmental Knowledge and natural hazards in Aotearoa - New Zealand, J. Roy. Soc. New Zeal., 37, 59-73, 2007.

King, D. N., Goff, J., Chague-Goff, C., McFadgen, B., Jacobson, G., Gadd, P., and Horrocks, M.: Reciting the layers: Evidence of past tsunamis at Mataora - Wairau Lagoon, Aotearoa-New Zealand, Mar. Geol., 389, 1-16, 2017.

Kovach, M.: Indigenous Methodologies: Characteristics, conversations and contexts, University of Toronto Press, Toronto, Canada, 201 pp., 2009.

Ludwin, R. S. and Smits, G. J.: Folklore and earthquakes: Native American oral tradition from Cascadia compared with written folklore from Japan, in: Myths and Geology, edited by: Piccardi, L. and Masse, W. B., Geological Society of London, Special Publication 273, 67-94, 2007.

Ludwin, R. S., Dennis, R., Carver, D., McMillan, A. D., Losey, R., Clague, J., Jonientz-Trisler, D., Bowechop, J., Wray, J., and James, K.: Dating the 1700 Cascadia Earthquake: Great Coastal Earthquakes in Native Stories, Seismol. Res. Lett., 76, 140-148, 2005.

Lum-Ho, W. K. and Lum-Ho, K.: Tsunamis in Hawaiian and Pacific Folklore and Ancient History, 18 pp., Pacific Tsunami Museum, 2005.

Masse, W. B., Wayland Barber, E., Piccardi, L., and Barber, P. T.: Exploring the nature of myth and its role in science, in: Myth and Geology, edited by: Piccardi, L. and Masse, W. B., Geological Society of London, Special Publications 273, 1-7, 2007.

McFadgen, B. G.: Hostile Shores: Catastrophic events in prehistoric New Zealand and their impact on Maori coastal communities, Auckland University Press, Auckland, 298 pp., 2007.

McFadgen, B. G. and Goff, J. R.: Tsunamis in the New Zealand archaeological record, Sediment. Geol., 200, 263-274, 2007.

McMillan, A. D. and Hutchinson, I. H.: When the Mountain Dwarfs Danced: Aboriginal Traditions of Paleoseismic Events along the Cascadia Subduction Zone of Western North America, Ethnohistory, 49, 41-68, 2002.

Mead, H. . Tikanga Māori: Living by Māori values, Huia Publishers, Wellington, 398 pp., 2003.

Meihana Whakapapa Book: Copies held in Ngati Kuia Archives, Te Rūnanga O Ngāti Kuia, Nelson, New Zealand, no date.

Mikaere, A.: The balance destroyed: The consequences for Māori women of the colonisation of tikanga Māori, Unpublished master's thesis, University of Waikato, Hamilton, New Zealand, 1995.
Mitchell, H. and Mitchell, J.: Te Tau Ihu o te Waka: A history of Maori of Marlborough and Nelson, Volume 1, Huia Publishers, Wellington, 500 pp., 2004.

Mustonen, T.: Window in the skies: indigenous memory, resistance and experience of Eurasia and the onslaught of resource extraction in the Arctic, Nordia Geographical Publications, 43, 67-73, 2014.

Nunn, P. D.: On the convergence of myth and reality: examples from the Pacific Islands, The Geographical Journal, 167, 125138, 2001.

Nunn, P. D. and Pastorizo, M. A. R.: Geological histories and geohazard potential of Pacific Islands illuminated by myths, in: Myths and Geology, edited by: Piccardi, L. and Masse, W. B., Geological Society of London, Special Publication 273, 143163, 2007.

Pearce, E. M. and Pearce, F. M.: The Context of Oral Traditions: The Oral Transmission of History and Maui the Navigators Visit to New Zealand, in: Oceanic Migration: Paths, Sequence, Timing and Range of Prehistoric Migration in the Pacific and Indian Oceans, edited by: Pearce, E. M. and Pearce, F. M., Springer, Dordrecht, 263-283, 2010.

Phillipson, G. A.: Rangahau District 13: The Northern South Island, Working Paper: First Release, Waitangi Tribunal, Rangahau Whanui Series, 258 pp., 1995.

Pidgeon, N.: Grounded theory: theoretical background, in: Handbook of Qualitative Research methods for Psychology and the Social Sciences, edited by: Richardson, J. E., British Psychological Society, Leicester, 240 pp., 1996.

Roberts, C. D., Stewart, A. L., and Struthers, C. D.: The Fishes of New Zealand - Volume Two, 1-576, Te Papa Press, Wellington, 2015a.

Roberts, C. D., Stewart, A. L., and Struthers, C. D.: The Fishes of New Zealand - Volume Four, 1153-1748, Te Papa Press, Wellington, 2015b.

Roberts, M.: Mind maps of the Maori, Geo-Journal, 77, 741-751, 2012.

Roberts, M. and Wills, P.: Understanding Maori epistemology - a scientific perspective, in: Tribal epistemologies: Essays in the philosophy of anthropology, edited by: Wautischer, H., Avebury, Ashgate, 43-77, 1998.

Royal, T. A. C.: Whakapapa, in: GRINZ Year Book, 21-25, Genealogical Research Institute of New Zealand, Lower Hutt, New Zealand, 1992.

Shaw, W. S., Herman, R. D. K., and Dobbs, G. R.: Encountering indigeneity: reimagining and decolonizing geography, Geogr. Ann. B, 88B, 267-276, 2006.

Smith, G. H.: Research Issues Related to Māori: The Issue of Research and Māori, in: Research Unit for Māori Education, edited by: Smith, G. H. and Hohepa, M., Monograph 9, University of Auckland, 47-69, 1990.

Smith, L. T.: Decolonising Methodologies - Research and Indigenous Peoples, Zed Books, London, 208 pp., 1999.

Smith, S. P.: Polynesian notes Volume 1, MS-Papers-1187-162, From: Polynesian society records (MS-Group-0677), Alexander Turnbull Library, Wellington, New Zealand, 1889.

Stephenson, J. and Moller, H.: Forum: foreword and analysis, Cross-cultural environmental research and management: challenges and progress, J. Roy. Soc. New Zeal., 39, 139-149, 2009. 
Stewart, R. K.: Final Report - Hawaiian Indigenous Knowledge of Natural Hazards, Pacific Tsunami Museum, 5 pp., 2009.

Styres, S.: The silent monologue: The voice within the space, Alternative 4, 89-101, 2008.

Te Awekotuku, N.: He Tikanga Whakaaro, Research Ethics in the Māori Community, Manutu Māori, Wellington, New Zealand, 29 pp., 1991.

Te Maire Tau: Matauranga Maori as epistemology, Te Pouhere Korero Journal, 1, 10-23, 1999.

Thrush, C. P. and Ludwin, R. S. Finding Fault: Indigenous Seismology, Colonial Science, and the Rediscovery of Earthquakes and Tsunamis of Cascadia, A. Indian Cult. Res. J., 31, 1-24, 2007.

Vitaliano, D.: Legends of the Earth; their Geologic Origins, Indiana University Press, Bloomington, USA, 305 pp., 1973.
Vitaliano, D. B.: Geomythology: geological origins of myths and legends, in: Myth and Geology, edited by: Piccardi, L. and Masse, W. B., Geological Society of London, Special Publications 273, 1-7, 2007.

Walters, R. A., Barnes, P., and Goff, J. R.: Locally generated tsunami along the Kaikoura coastal margin: Part 1, Fault ruptures, New Zea. J. Mar. Fresh., 40, 1-16, 2006.

Zanotti, L. and Palomino-Schalsha, M.: Taking different ways of knowing seriously: cross-cultural work as translations and multiplicity, Weaving Indigenous and sustainability sciences to diversify our methods, Sustain. Sci., 11, 139-152, 2006. 